\title{
ANALISIS DAN PERANCANGAN DATA WAREHOUSE PADA PT PELITA TATAMAS JAYA
}

\author{
Choirul Huda; Jumas Ranope; Marly Lumenta; Kevin \\ Jurusan Teknologi Informasi, Fakultas Ilmu Komputer, Bina Nusantara University \\ Jln. KH. Syahdan No 9, Palmerah, Jakarta Barat 11480, \\ ChoirulHuda@binus.edu
}

\begin{abstract}
The purpose of this research is to assist in providing information to support decision-making processes in sales, purchasing and inventory control at PT Tatamas Pelita Jaya. With the support of data warehouse, business leaders can be more helpful in making decisions more quickly and precisely. Research methodology includes analysis of current systems, library research, designing a data warehousing schema using bintang. The result of this research is the availability of a data warehouse that can generate information quickly and precisely, thus helping the company in making decisions. The conclusion of this research is the application of data warehouse can be a media aide related parties on PT Tatamas Pelita Jaya in decision making.
\end{abstract}

Keywords: data, information, data warehouse.

\begin{abstract}
ABSTRAK
Tujuan dari penelitian ini adalah untuk membantu penyediaan informasi dalam mendukung proses pengambilan keputusan bidang penjualan, pembelian dan kontrol persediaan pada PT Pelita Tatamas Jaya. Dengan dukungan data warehouse, pimpinan perusahaan dapat lebih terbantu dalam pengambilan keputusan yang lebih cepat dan tepat. Metode penelitian yang dilakukan meliputi analisa sistem yang sedang berjalan, studi pustaka, merancang data warehouse dengan metode skema bintang. Hasil dari penelitian ini adalah tersedianya data warehouse yang dapat menghasilkan informasi yang cepat dan tepat, sehingga membantu pihak perusahaan dalam mengambil keputusan. Kesimpulan dari penelitian ini adalah aplikasi data warehouse ini dapat menjadi media pembantu pihak terkait pada PT Pelita Tatamas Jaya dalam pengambilan keputusan.
\end{abstract}

Kata kunci: data, informasi, data warehouse. 


\section{PENDAHULUAN}

Perkembangan teknologi informasi yang semakin pesat turut memacu perkembangan pada dunia bisnis untuk mampu mengikuti perubahan yang terjadi dan menjadi lebih maju lagi. Seiring dengan semakin berkembangnya dunia bisnis ini, semakin dibutuhkan pula data dan informasi yang lengkap dan akurat untuk membantu kegiatan perencanaan, pengendalian, dan pengambilan keputusan yang berkaitan dengan pengelolaan dan pengembangan bisnis.

Kesuksesan pada kompetisi dalam dunia bisnis dan dibarengi dengan upaya pengembangan bisnis yang semakin pesat, dipengaruhi oleh kemampuan untuk melihat kecenderungan bisnis di masa mendatang, mengoptimalkan produktivitas dan efektivitas kegiatan bisnis, serta penentuan strategi dan kebijakan bisnis yang tepat. Oleh karena itu, berbagai data dan informasi yang berkaitan dengan hal tersebut harus disusun sedemikian rupa sehingga mudah diakses, dapat diintegrasikan, serta dapat tersedia tepat waktu saat dibutuhkan.

Penting sekali bagi pihak manajemen perusahaan terutama pihak pimpinan perusahaan untuk dapat menentukan berbagai keputusan maupun kebijakan yang terkait dengan pengembangan dan pencapaian tujuan strategis bisnis serta visi perusahaan ke depannya secara cepat dan tepat. Ditambah lagi dengan adanya permintaan terhadap barang yang sering berubah tergantung pada berbagai macam situasi dan kondisi pasar membuat pihak perusahaan harus mampu menentukan strategi bisnis yang tepat agar dapat mengimbangi perubahan tersebut.

PT Pelita Tatamas Jaya merupakan perusahaan yang bergerak dalam bidang perdagangan dan distribusi berbagai produk besi dan baja, dalam kegiatan operasionalnya telah memanfaatkan teknologi informasi dan sistem informasi sebagai basis utama. Dengan melibatkan database sebagai pendukung utama kegiatan operasional oleh perusahaan dirasakan cukup baik tetapi masalah timbul ketika pihak pimpinan perusahaan ingin melihat perkembangan perusahaan dari tahun ke tahun, aplikasi yang dipakai sekarang tidak mendukung hal tersebut, karena aplikasi database biasanya bersifat kompleks, belum dikelompokkan berdasarkan kategori tertentu sehingga sulit untuk dipahami terutama oleh pihak pimpinan perusahaan yang biasanya harus melihat ribuan data perusahaan saat membuat keputusan sehingga prosesnya dapat memakan waktu berhari-hari bahkan berminggu-minggu. Untuk lebih mengefektifkan kegiatannya, maka dibutuhkan suatu teknologi yang dapat mengintegrasikan dan menyimpan data (repository) agar data tersebut dapat diolah secara cepat dan akurat sehingga dapat digunakan untuk pengambilan keputusan. Berdasarkan fakta di atas, PT Pelita Tatamas Jaya menyadari pentingnya ketersediaan data dan informasi untuk pengambilan keputusan. Oleh sebab itu, diperlukan suatu analisis dan perancangan Data Warehouse untuk dapat memenuhi kebutuhan tersebut.

\section{METODE}

Metode yang digunakan dalam penelitian ini meliputi analisis, perancangan, dilanjutkan dengan pembuatan program, pengujian dan evaluasi. Analisis dilakukan terhadap kondisi perusahaan, analisa kekuatan, kelemahan, peluang, dan ancaman sehingga dapat diidentifikasi kebutuhan perusahaan. Perancangan data warehouse dengan penerapan skema bintang, termasuk rancangan arsitekturnya. Skema bintang adalah suatu desain database yang paling sering digunakan untuk merealisasikan sebuah data warehouse, memiliki struktur sederhana dengan tabel-tabel yang relatif dan penggabungan yang telah diketahui. Dengan kata lain, merupakan sebuah struktur sederhana yang menghubungkan beberapa tabel beserta masing-masing primary key-nya dan dirumuskan dengan baik sehingga membentuk suatu tabel baru yang terdiri dari field-field dari tabel-tabel tersebut. 
Pembuatan program dilakukan denganmenggunakan alat bantu pemograman Microsoft Visual Basic 6.0. Pengujian dan evaluasi dilakukan oleh pengguna dengan menggunakan program aplikasi yang sudah disediakan.

\section{HASIL DAN PEMBAHASAN}

\section{Visi dan Misi}

Sesuai dengan visi perusahaan yang bergerak dalam bidang kegiatan perdagangan besi dan baja maka PT. Pelita Tatamas Jaya memiliki misi untuk dapat bersaing dengan perusahaan yang bergerak dibidang sejenis di seluruh Indonesia. Sasaran yang ingin dicapai oleh perusahaan dalam kurun waktu lima tahun kedepan adalah meningkatkan volume penjualan secara bertahap namun berkesinambungan sehingga dapat mewujudkan cita-citanya untuk menjadi distributor utama di wilayah Jakarta dan sekitarnya.

\section{Faktor-Faktor Kritis}

Critical Success Factor (CSF) adalah faktor yang menentukan dan mempengaruhi kemampuan suatu perusahaan atau organisasi untuk mencapai sasarannya dan membantu untuk mendefinisikan kebutuhan apa saja yang dibutuhkan. Perusahaan menetapkan Critical Success Factornya yaitu nilai penjualan secara keseluruhan harus meningkat minimal $10 \%-20 \%$ per tahun. Nilai penjualan yang dimaksud adalah nilai uang yang diterima bukan jumlah barang yang dijual.

\section{Subyek Data}

Subyek data merupakan data yang menjadi sumber atau masukkan yang dibutuhkan di dalam sistem yang dikelompokkan menjadi suatu kelompok tertentu. Subyek data digunakan untuk mendapatkan sumber-sumber data yang berfungsi sebagai informasi yang diperlukan bagi pihak eksekutif. Adapun subyek data yang terdapat dalam perusahaan dan digunakan sebagai sumber data dalam penelitian ini adalah sebagai berikut:

Tabel 1 Subjek Data

\begin{tabular}{|c|c|c|}
\hline No. & Subyek Data & Keterangan \\
\hline 1. & Barang & $\begin{array}{l}\text { Berisi informasi mengenai berbagai produk besi dan baja yang } \\
\text { diperdagangkan oleh pihak perusahaan. }\end{array}$ \\
\hline 2. & Supplier & $\begin{array}{l}\text { Berisi informasi mengenai supplier yang memasok barang kepihak } \\
\text { perusahaan. }\end{array}$ \\
\hline 3. & Pelanggan & $\begin{array}{l}\text { Berisi informasi mengenai pelanggan yang membeli barang dari } \\
\text { perusahaan. }\end{array}$ \\
\hline 4. & Gudang & Berisi informasi mengenai lokasi gudang penyimpanan. \\
\hline 5. & Quotation PO & $\begin{array}{l}\text { Berisi informasi mengenai penawaran barang dari pihak supplier ke } \\
\text { pihak perusahaan }\end{array}$ \\
\hline 6. & Purchase Order (PO) & $\begin{array}{l}\text { Berisi informasi mengenai bukti pembelian barang ke supplier } \\
\text { berdasarkan pemesanan yang dilakukan sebelumnya. }\end{array}$ \\
\hline 7. & $\begin{array}{l}\text { Bukti Penerimaan Barang } \\
\text { (BPB) }\end{array}$ & $\begin{array}{l}\text { Berisi informasi mengenai bukti penerimaan barang yang dibeli } \\
\text { dari supplier. }\end{array}$ \\
\hline 8. & Nota Pembayaran & $\begin{array}{l}\text { Berisi informasi mengenai pembayaran yang akan dilakukan oleh } \\
\text { perusahaan atas PO yang dikeluarkan ke pihak supplier dan } \\
\text { disesuaikan dengan BPB atas PO tersebut. }\end{array}$ \\
\hline 9. & $\begin{array}{l}\text { Retur Pembelian Barang } \\
\text { (RPB) }\end{array}$ & Berisi informasi atas bukti retur pembelian barang ke pihak supplier \\
\hline 10. & Quotation DO & Berisi informasi mengenai penawaran barang yang dilakukan oleh \\
\hline
\end{tabular}




\begin{tabular}{|c|c|c|}
\hline & & ggan. \\
\hline 11. & Delivery Order (DO) & risi informasi mengenai bukti penjualan barang ke pelanggan \\
\hline 12. & Surat Jalan (SJ) & $\begin{array}{l}\text { Berisi informasi mengenai bukti pengiriman barang yang dibeli } \\
\text { leh pelanggan. }\end{array}$ \\
\hline 13. & Invoice & $\begin{array}{l}\text { Berisi informasi mengenai surat tagihan pembayaran atas DO yang } \\
\text { dikeluarkan ke pihak pelanggan dan disesuaikan dengan SJ atas DO } \\
\text { tersebut. }\end{array}$ \\
\hline 14. & $\begin{array}{l}\text { Retur Penjualan Barang } \\
\text { (RPJ) }\end{array}$ & $\begin{array}{l}\text { Berisi informasi atas bukti retur penjualan barang dari pihak } \\
\text { pelanggan. }\end{array}$ \\
\hline 15. & Mutasi Barang Gudang & $\begin{array}{l}\text { Berisi informasi mengenai perpindahan sejumlah barang dari satu } \\
\text { lokasi gudang ke lokasi gudang yang lain. }\end{array}$ \\
\hline 16. & Stok Barang & $\begin{array}{l}\text { Berisi informasi mengenai jumlah setiap barang yang tersedia di } \\
\text { gudang. }\end{array}$ \\
\hline
\end{tabular}

\section{Fungsi Bisnis}

Fungsi bisnis merupakan kelompok aktivitas yang bersama-sama mendukung salah satu aspek misi dari perusahaan dan adakalanya di kelompokkan ke dalam area fungsi (functional area) serta dilakukan terus-menerus secara berkesinambungan atau dengan kata lain, fungsi bisnis adalah kegiatan-kegiatan yang dilakukan oleh pihak perusahaan berdasarkan fungsi tiap-tiap bagian. Kegiatan ini menyusun aktivitas yang dilakukan oleh perusahaan dalam menjalankan operasional perusahaan.

Fungsi bisnis yang dikelompokkan ke dalam functional area sebagai contohnya, dalam perusahaan PT Pelita Tatamas Jaya terdapat terdapat area fungsi Penjualan, Pembelian, dan Kontrol Stok. Dari area fungsi tersebut seperti Kontrol Stok terdapat fungsi bisnis seperti Pemeriksaan Stok Barang dan Mutasi Barang Gudang. Dalam penelitian ini fungsi bisnis yang menjadi fokus pembahasan adalah area fungsi Penjualan, Pembelian dan Kontrol Stok, di mana penjelasan rincian fungsi bisnisnya masing-masing dapat dilihat pada tabel berikut ini.

Tabel 2 Fungsi Bisnis untuk kegiatan pembelian

\begin{tabular}{cll}
\hline No. & Fungsi Bisnis & Keterangan \\
\hline 1 & Pemesanan Barang & Kegiatan pemesanan barang-barang yang diinginkan ke \\
& & pihak supplier diikuti dengan pencatatan atas penawaran \\
& & yang dikirimkan oleh supplier tersebut ke pihak perusahaan.
\end{tabular}

2 Pembuatan Surat PO Barang

3 Penerimaan Barang

4 Pengurusan Retur Pembelian

5 Pembuatan Nota Pembayaran
Kegiatan membuat surat Purchase Order atas barang-barang yang telah dipesan sebelumnya ke pihak supplier atau dengan kata lain sebagai surat resmi pembelian barang ke pihak supplier.

Kegiatan penerimaan barang yang dikirim dari pihak supplier disertai dengan pencatatan atas barang yang diterima pada surat bukti penerimaan barang (BPB).

Kegiatan yang mengurusi retur pembelian barang ke pihak supplier.

Kegiatan membuat surat pembayaran atas invoice yang diterima dari pihak supplier. 
Tabel 3 Fungsi Bisnis untuk Kegiatan Penjualan

\begin{tabular}{|c|c|c|}
\hline No. & Fungsi Bisnis & Keterangan \\
\hline 1 & Penawaran Barang & $\begin{array}{l}\text { Kegiatan penawaran atas barang-barang yang akan dijual } \\
\text { perusahaan kepada pihak pelanggan. }\end{array}$ \\
\hline 2 & Pembuatan Surat DO Barang & $\begin{array}{l}\text { Kegiatan membuat surat Delivery Order atas barang-barang } \\
\text { yang telah dipesan sebelumnya oleh pihak pelanggan atau } \\
\text { dengan kata lain sebagai surat resmi penjualan barang ke } \\
\text { pihak pelanggan. }\end{array}$ \\
\hline 3 & Pengeluaran Barang & $\begin{array}{l}\text { Kegiatan pengeluaran barang dari gudang disertai dengan } \\
\text { pembuatan surat jalan (SJ) sebagai dokumen pengiriman } \\
\text { barang ke pihak pelanggan. }\end{array}$ \\
\hline 4 & Pengurusan Retur Penjualan & $\begin{array}{l}\text { Kegiatan yang mengurusi retur penjualan barang dari pihak } \\
\text { pelanggan. }\end{array}$ \\
\hline 5 & Pembuatan Invoice & $\begin{array}{l}\text { Kegiatan membuat surat tagihan atas pesanan barang yang } \\
\text { dikirim ke pihak pelanggan. }\end{array}$ \\
\hline
\end{tabular}

Tabel 4 Fungsi Bisnis untuk Kegiatan Kontrol Stok

\begin{tabular}{cll}
\hline No. & Fungsi Bisnis & Keterangan \\
\hline 1 & Pemeriksaan Stok Barang & $\begin{array}{l}\text { Kegiatan pengecekan jumlah barang-barang yang tersedia di } \\
\text { gudang dalam rangka memberikan informasi untuk proses } \\
\text { pembelian barang yang dibutuhkan dalam memperlancar } \\
\text { kegiatan penjualan barang ke pihak pelanggan. }\end{array}$ \\
& & $\begin{array}{l}\text { Kegiatan pengalokasian barang-barang yang tersimpan antar } \\
\text { gudang yang ada. }\end{array}$ \\
\hline
\end{tabular}

\section{Matrik}

Matrik digunakan sebagai penjelas keterkaitan atau hubungan antara dua aspek dalam sistem yang sedang berjalan. Dibuat dalam format tabel yang berisi nilai ' $x$ ' artinya terdapat hubungan sedangkan '-' artinya tidak ada hubungan. Untuk mengetahui hubungan antara unit-unit organisasi yang ada di PT. Pelita Tatamas Jaya khususnya yang berkaitan langsung dengan kegiatan pembelian, penjualan dan pengendalian stok dengan faktor lokasi, dapat dilihat pada matriks berikut :

Tabel 5 Matriks Unit Organisasi versus Lokasi

UNIT
ORGANISASI


Untuk mengetahui hubungan antara unit-unit organisasi yang terlibat secara langsung dalam kegiatan operasional penjualan, pembelian dan kontrol persediaan yang ada di PT. Pelita Tatamas Jaya dengan subyek data yang digunakan, dapat dilihat pada matriks berikut:

Tabel 6 Matriks Unit Organisasi Versus Subyek Data

\begin{tabular}{|c|c|c|c|c|c|c|c|c|c|c|c|c|c|c|c|c|}
\hline $\begin{array}{r}\text { SUBYEK } \\
\text { DATA }\end{array}$ & 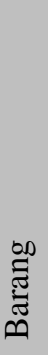 & 离 & 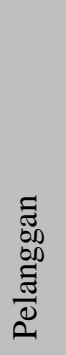 & 䠐 & 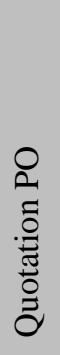 & $\stackrel{0}{\varrho}$ & $\frac{n}{\stackrel{n}{n}}$ & 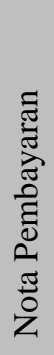 & 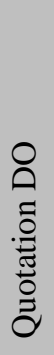 & ○̊ & $\vec{\omega}$ &.$\stackrel{0}{0}$ & $\frac{n}{\underline{a}}$ & $\overrightarrow{\underline{\sim}}$ & 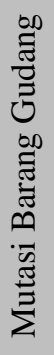 & 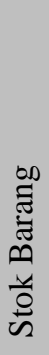 \\
\hline Bagian Order Penjualan & $\mathrm{x}$ & - & $\mathrm{x}$ & $\mathrm{x}$ & - & - & - & - & $\mathrm{x}$ & $\mathrm{x}$ & $\mathrm{x}$ & - & - & $\mathrm{x}$ & - & $\mathrm{x}$ \\
\hline Bagian Pembelian & $\mathrm{x}$ & $\mathrm{x}$ & - & $\mathrm{x}$ & $\mathrm{x}$ & $\mathrm{x}$ & $\mathrm{x}$ & - & - & - & - & - & $\mathrm{x}$ & - & - & $\mathrm{x}$ \\
\hline Bagian Penerimaan & $\mathrm{x}$ & $\mathrm{x}$ & - & $\mathrm{x}$ & $\mathrm{x}$ & $\mathrm{x}$ & $\mathrm{x}$ & - & - & - & - & - & $\mathrm{x}$ & - & - & $\mathrm{x}$ \\
\hline Bagian Pengeluaran & $\mathrm{x}$ & - & $\mathrm{x}$ & $\mathrm{x}$ & - & - & - & - & $\mathrm{x}$ & $\mathrm{x}$ & $\mathrm{x}$ & - & - & $\mathrm{x}$ & - & $\mathrm{x}$ \\
\hline Bagian Gudang & $\mathrm{x}$ & $\mathrm{x}$ & $\mathrm{x}$ & $\mathrm{x}$ & - & - & $\mathrm{x}$ & - & - & - & $\mathrm{x}$ & - & $\mathrm{x}$ & $\mathrm{x}$ & $\mathrm{x}$ & $\mathrm{x}$ \\
\hline Bagian Piutang & $\mathrm{x}$ & - & $\mathrm{x}$ & - & & - & - & - & $\mathrm{x}$ & $\mathrm{x}$ & $\mathrm{x}$ & $\mathrm{x}$ & - & $\mathrm{x}$ & - & - \\
\hline Bagian Hutang & $\mathrm{x}$ & $\mathrm{X}$ & - & - & $\mathrm{X}$ & $\mathrm{x}$ & $\mathrm{x}$ & $\mathrm{x}$ & - & - & - & - & $\mathrm{x}$ & - & - & - \\
\hline
\end{tabular}

Untuk mengetahui hubungan antara unit-unit organisasi yang ada di perusahaan dengan fungsi bisnis yang dilakukan, khususnya yang terlibat secara langsung dalam kegiatan penjualan, pembelian dan kontrol persediaan, dapat dilihat pada matriks berikut:

Tabel 7 Matriks Unit Organisasi versus Fungsi Bisnis

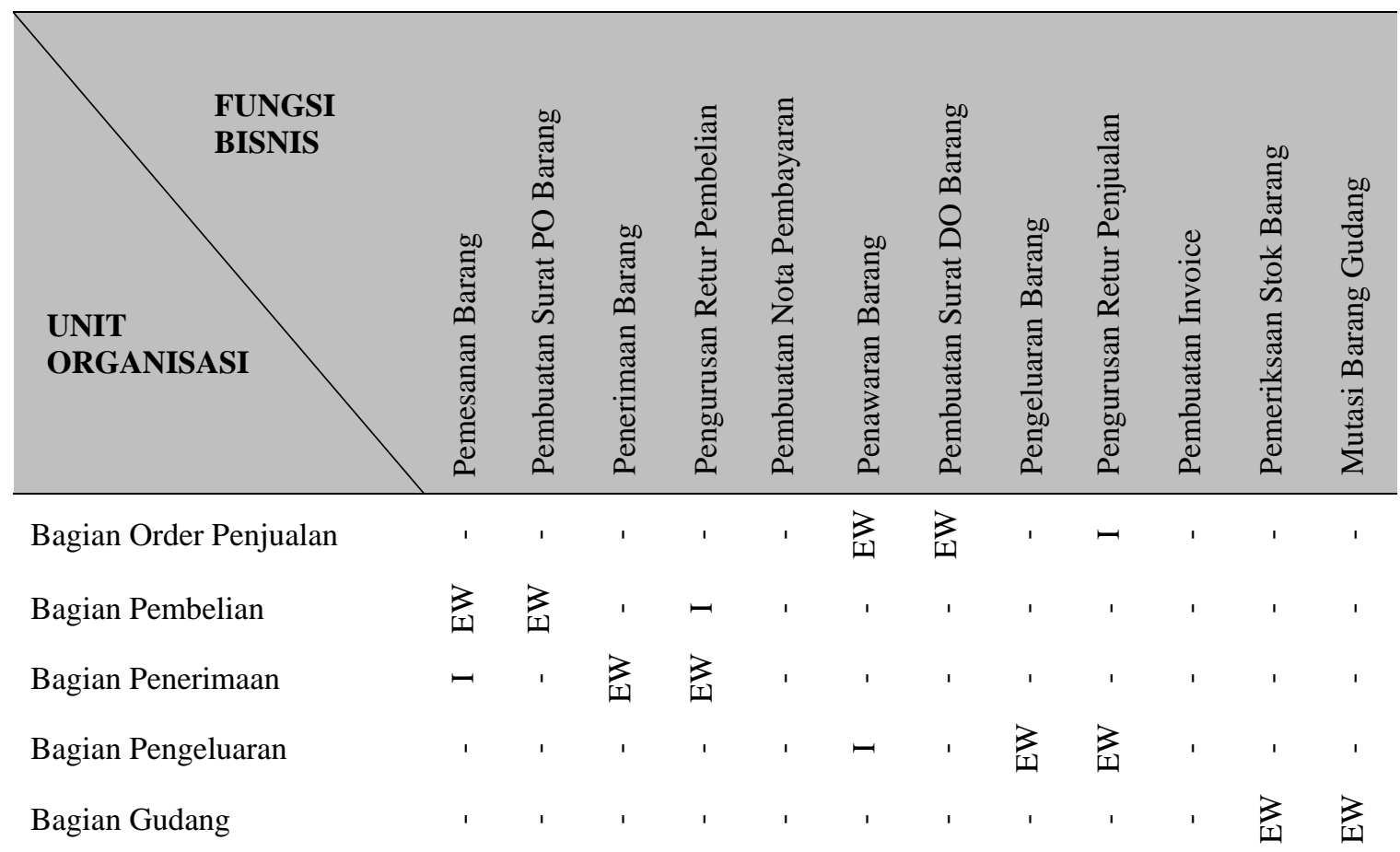


Bagian Piutang

Bagian Hutang

Keterangan isi tabel adalah sebagai berikut :

R : Direct management responsibility

Unit organisasi yang bertanggung jawab secara langsung atas kegiatan yang dilakukan pada fungsi bisnis yang berkaitan.

A : Executive or Policy making authority

Unit organisasi yang memiliki kewenangan dalam membuat dan melaksanakan kebijaksanaan pada fungsi bisnis yang berkaitan.

I : Involved in the function

Unit organisasi yang terkait pada fungsi bisnis tetapi tidak bertanggung jawab dan tidak memiliki kuasa terhadap fungsi bisnis tersebut.

E : Technical expertise

Unit organisasi yang memiliki keahlian teknis dalam menjalankan fungsi bisnis

W : Actual execution of the work

Unit organisasi yang melaksanakan seluruh kegiatan yang terdapat pada fungsi bisnis yang berkaitan.

Untuk mengetahui hubungan antara eksekutif yang ada di PT. Pelita Tatamas Jaya, meliputi pihak pimpinan dan para manajer-nya dengan fungsi bisnis yang dilakukan, dapat dilihat pada matriks berikut:

Tabel 8 Matriks Eksekutif versus Fungsi Bisnis

\begin{tabular}{|c|c|c|c|c|c|c|c|c|c|c|c|c|}
\hline $\begin{array}{l}\text { FUNGSI } \\
\text { BISNIS }\end{array}$ & 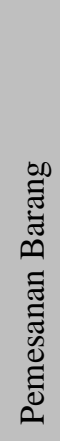 & 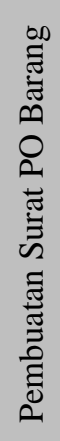 & 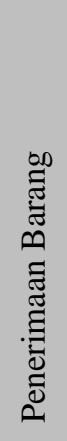 & 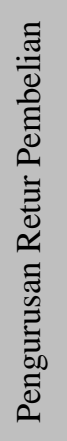 & 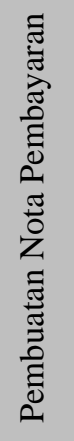 & 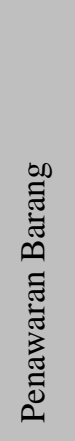 & 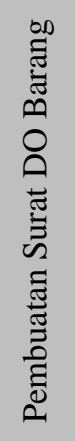 & 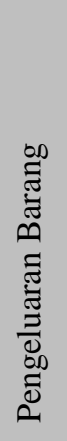 & 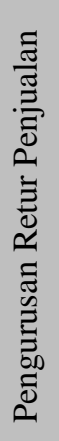 & 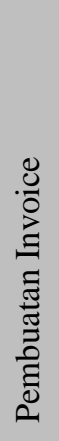 & 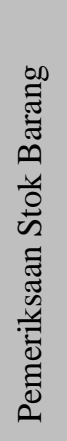 & 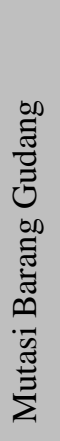 \\
\hline Direktur & $\varangle$ & 1 & 1 & 1 & $\varangle$ & $\varangle$ & 1 & 1 & ' & $\varangle$ & $\varangle$ & $\varangle$ \\
\hline Manajer Personalia & ' & ' & 1 & 1 & ' & 1 & ' & 1 & ' & ' & ' & ' \\
\hline Manajer Penjualan & ' & ' & ' & ' & ' & 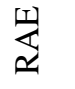 & $\simeq$ & ' & $\neg$ & ' & ' & ' \\
\hline Manajer Pembelian & 政 & $\simeq$ & 1 & 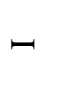 & ' & 1 & 1 & 1 & ' & ' & ' & ' \\
\hline Manajer Persediaan & 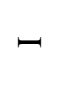 & ' & s & $\simeq$ & ' & 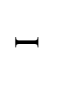 & ' & r & $\simeq$ & ' & 委 & 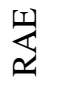 \\
\hline Manajer Keuangan & 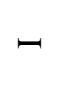 & ' & ' & ' & 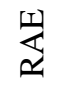 & $\neg$ & ' & 1 & 1 & 臹 & ' & ' \\
\hline Manajer IT & ' & ' & ' & ' & ' & ' & ' & ' & ' & ' & ' & ' \\
\hline
\end{tabular}


Keterangan dari isi tabel adalah sebagai berikut :

R : Direct management responsibility

Unit organisasi yang bertanggung jawab secara langsung atas kegiatan yang dilakukan pada fungsi bisnis yang berkaitan.

A : Executive or Policy making authority

Unit organisasi yang memiliki kewenangan dalam membuat dan melaksanakan kebijaksanaan pada fungsi bisnis yang berkaitan.

I : Involved in the function

Unit organisasi yang terkait pada fungsi bisnis tetapi tidak bertanggung jawab dan tidak memiliki kuasa terhadap fungsi bisnis tersebut.

E : Technical expertise

Unit organisasi yang memiliki keahlian teknis dalam menjalankan fungsi bisnis

W : Actual execution of the work

Unit organisasi yang melaksanakan seluruh kegiatan yang terdapat pada fungsi bisnis yang berkaitan.

Untuk mengetahui hubungan antara fungsi bisnis yang ada di PT. Pelita Tatamas Jaya dengan penggunaan subyek data yang tersedia, dapat dilihat pada matriks berikut:

Tabel 9 Matriks Fungsi Bisnis versus Subyek Data

\begin{tabular}{|c|c|c|c|c|c|c|c|c|c|c|c|c|c|c|c|c|}
\hline $\begin{array}{l}\text { FUNGSI } \\
\text { BISNIS }\end{array}$ & 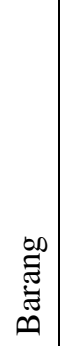 & 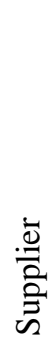 & 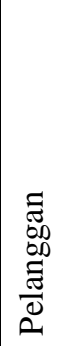 & 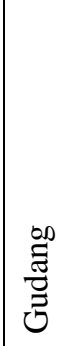 & 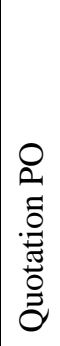 & $\stackrel{ి}{\curvearrowright}$ & $\stackrel{\infty}{\infty}$ & 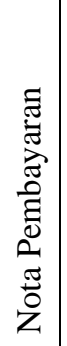 & 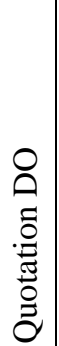 & ○ & $\bar{n}$ & $\begin{array}{l}\stackrel{\mathscr{U}}{0} \\
\stackrel{\Xi}{\Xi} \\
.\end{array}$ & 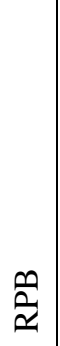 & م્વ & 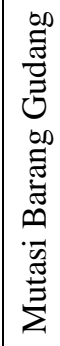 & 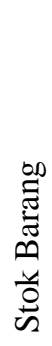 \\
\hline Pemesanan Barang & $\simeq$ & $\simeq$ & ' & 1 & S: & ' & ' & ' & ' & ' & ' & ' & ' & ' & ' & , \\
\hline Pembuatan Surat PO Barang & $\simeq$ & $\simeq$ & 1 & ' & $\simeq$ & 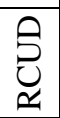 & ' & ' & ' & ' & ' & 1 & 1 & ' & ' & ' \\
\hline Penerimaan Barang & $\simeq$ & $\simeq$ & ' & $\simeq$ & $\simeq$ & $\simeq$ & $\underbrace{}_{\mathscr{x}}$ & ' & ' & ' & ' & ' & ' & ' & ' & 兄 \\
\hline Pengurusan Retur Pembelian & $\simeq$ & $\simeq$ & 1 & $\simeq$ & ' & $\simeq$ & $\simeq$ & 1 & 1 & 1 & 1 & ' & 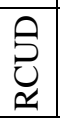 & 1 & 1 & $\vec{x}$ \\
\hline Pembuatan Nota Pembayaran & $\simeq$ & $\simeq$ & ' & ' & ' & $\simeq$ & $\simeq$ & 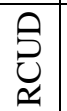 & ' & ' & 1 & 1 & $\simeq$ & 1 & ' & ' \\
\hline Penawaran Barang & $\simeq$ & ' & $\simeq$ & ' & 1 & 1 & ' & ' & 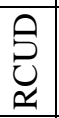 & ' & ' & ' & ' & ' & ' & , \\
\hline Pembuatan Surat DO Barang & $\simeq$ & ' & r & ' & ' & 1 & ' & ' & $\simeq$ & 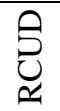 & 1 & 1 & 1 & ' & ' & ' \\
\hline Pengeluaran Barang & $\simeq$ & 1 & $\simeq$ & $\simeq$ & ' & 1 & 1 & 1 & $\simeq$ & $\simeq$ & 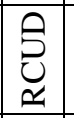 & 1 & ' & ' & ' & 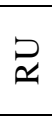 \\
\hline Pengurusan Retur Penjualan & $\simeq$ & ' & $\simeq$ & $\simeq$ & 1 & ' & ' & 1 & 1 & $\simeq$ & $\simeq$ & ' & ' & 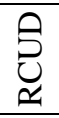 & 1 & $\stackrel{2}{x}$ \\
\hline
\end{tabular}




\begin{tabular}{|c|c|c|c|c|c|c|c|c|c|c|c|c|c|c|c|c|}
\hline Pembuatan Invoice & $\simeq$ & 1 & $\simeq$ & 1 & 1 & 1 & 1 & 1 & 1 & $\simeq$ & $\simeq$ & 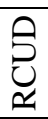 & 1 & $\simeq$ & 1 & 1 \\
\hline Pemeriksaan Stok Barang & $\simeq$ & 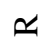 & $\simeq$ & $\simeq$ & 1 & 1 & 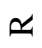 & 1 & 1 & 1 & $\simeq$ & 1 & $\simeq$ & $\simeq$ & $\simeq$ & 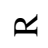 \\
\hline Mutasi Barang Gudang & $\simeq$ & $\simeq$ & $\simeq$ & $\simeq$ & 1 & 1 & 1 & 1 & 1 & 1 & 1 & ' & 1 & ' & Sి & $\beth_{\alpha}$ \\
\hline
\end{tabular}

Keterangan dari isi adalah sebagai berikut :

$\mathrm{C}$ : Create, Menciptakan subyek data untuk melaksanakan fungsi bisnis

$\mathrm{R}$ : Read, Pembacaan subyek data dalam melaksanakan fungsi bisnis

$\mathrm{U}$ : Update, Perubahan subyek data dalam melaksanakan fungsi bisnis

D : Delete, Penghapusan subyek data dalam melaksanakan fungsi bisnis

Dalam menjalankan fungsi bisnisnya, PT. Pelita Tatamas Jaya telah menggunakan bantuan teknologi informasi. Teknologi Informasi yang digunakan tersebut meliputi aspek perangat keras maupun piranti lunak termasuk dukungan program aplikasi. Untuk mengetahui hubungan antara fungsi bisnis yang ada di PT. Pelita Tatamas Jaya dengan pemanfaatan aplikasi yang tersedia, dapat dilihat pada matriks berikut:

Tabel 10 Matriks Fungsi Bisnis vs Aplikasi

APLIKASI
BISNIS
PUNGI

Untuk mengetahui hubungan antara subyek data yang ada di PT. Pelita Tatamas Jaya dengan pemanfaatan aplikasi yang tersedia, dapat dilihat pada matriks berikut: 


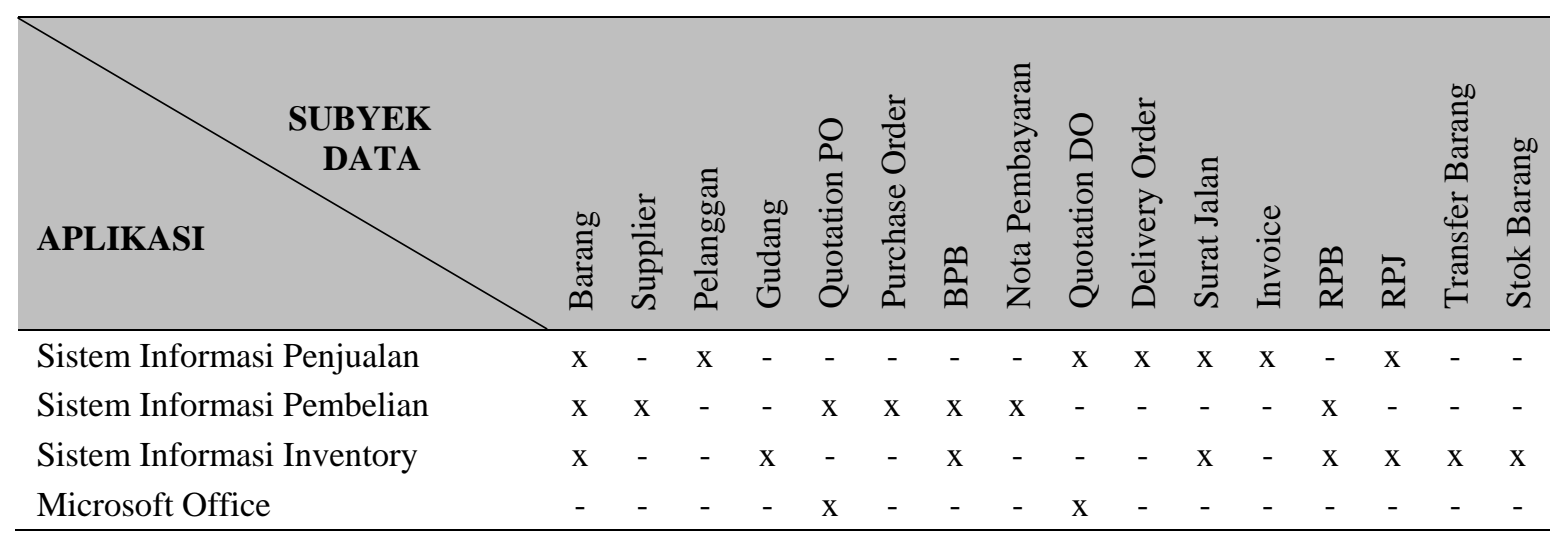

\section{Kebutuhan Informasi}

Untuk mendukung pihak terkait dalam pengambilan keputusan, dibutuhkan informasi tingkat penjualan barang, informasi tingkat pembelian barang dari, informasi mengenai tingkat perbandingan antara pembelian barang dengan retur pembelian dan juga atas tingkat perbandingan antara penjualan barang dengan retur penjualan dalam, informasi mengenai jumlah barang masuk dan barang keluar dari tempat penyimpanan barang atau gudang yang ada di perusahaan.Informasi tersebut dapat disajikan per periode bulan, kuartal, semester bahkan per tahunnya.Dibutuhkan juga informasi mengenai tingkat persentase pertumbuhan nilai penjualan barang dan pertumbuhan nilai pembelian barang yang dilihat dari jumlah bayar dari satu periode tahun ke tahun berikutnya.

\section{Permasalahan}

Sering tekadnya untuk menjadi perusahaan yang maju baik dalam hal penjualan maupun pelayanannya, perusahaan masih memiliki masalah terkait pengaturan dan penggunaan data perusahaan, meliputi tidak tersedianya fasilitas yang dibutuhkan untuk mendukung kegiatan analisis sebagai dasar pengambilan keputusan oleh pihak eksekutif. Hal ini menyebabkan pada saat melakukan analisis terhadap data historis akan membutuhkan waktu cukup lama dan cukup menyulitkan untuk mencari data dan informasi yang diinginkan. Pemecahan masalah yang diusulkan adalah dengan membangun sebuah Data Warehouse di PT. Pelita Tatamas Jaya sebagai pendukung dalam kegiatan analisis perusahaan.

\section{Rancangan Arsitektur}

Rancangan arsitektur data warehouse yang diusulkan menggunakan arsitektur data warehouse terpusat. Komponen-komponen dari arsitektur data warehouse terpusat yang diusulkan meliputi sumber data, transformasi data, data warehouse, aplikasi untuk pengguna. Sumber data berasal dari data operasional yang sudah dimiliki perusahaan. Data operasional ini mencakup pengawasan stok persediaan barang, penjualan barang, pembelian barang

Komponen transformasi data digunakan untuk melakukan ekstrak dan transformasi data dari sumber data ke ke dalam data warehouse. Komponen data warehouse merupakan komponen yang berguna untuk menyimpan data-data yang sudah tersaring. Data yang tersimpan bersifat historical dengan jangka waktu tertentu. Selain itu, data ini dapat digunakan untuk membantu dalam melakukan analisa terhadap transaksi yang telah terjadi sebelumnya. Data warehouse juga bersifat konsisten dan terjamin integritasnya sehingga informasi yang dihasilkan akurat dan tepat. Komponen aplikasi berperan sebagai jembatan penghubung antara data warehouse dengan pemakainya, sehingga pemakai 
lebih terbantu dalam menggunakan data warehouse. Lebih detil arsitektur yang diusulkan seperti nampak pada gambar di bawah ini.

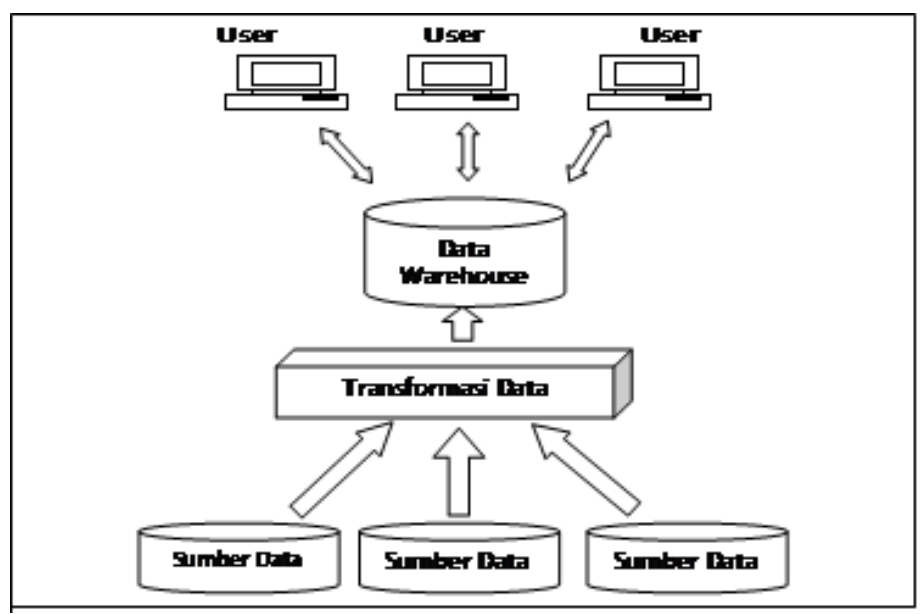

Gambar 1 Arsitektur Data Warehouse PT. Pelita Tatamas Jaya

\section{Rancangan Skema Bintang}

Data warehouse yang diusulkan, dirancang dengan skema bintang yang terdiri dari tabel-tabel yang berfungi sebagai fakta disertai tabel-tabel yang berfungsi sebagai dimensi.Terdapat tiga skema bintang meliputi skema bintang penjualan, skema bintang pembelian, skema bintang stok kontrol.

Skema Bintang Penjualan menunjukkan kegiatan Penjualan ke Pelanggan. Pada skema ini dapat dilihat harga satuan barang, persentase diskon per barang, persentase dan nilai rupiah ppn, jumlah barang yang terjual, jumlah barang yang dibayar oleh pelanggan, jumlah barang yang diretur, dan jumlah pembayaran sebelum maupun sesudah dikenai pajak. Data tersebut dapat dilihat berdasarkan dimensi Waktu, dimensi Barang, dimensi Pembayaran, dimensi Satuan, dimensi Pelanggan, dan dimensi Signature.

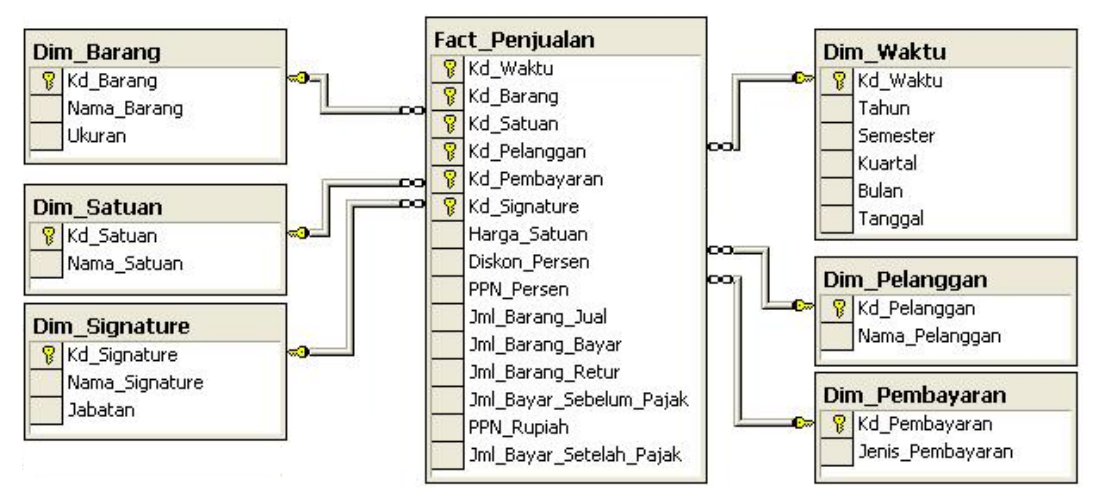

Gambar 2 Skema Bintang Fakta Penjualan

Skema Bintang Pembelian menunjukkan kegiatan Pembelian dari Supplier ke Perusahaan. Informasi yang dapat diperoleh dari skema bintang ini adalah harga satuan barang, persentase diskon per barang, persentase dan nilai rupiah ppn, jumlah barang yang terjual, jumlah barang yang dibayar oleh perusahaan, jumlah barang yang diretur ke supplier, dan jumlah pembayaran sebelum maupun 
sesudah dikenai pajak. Data dapat dilihat berdasarkan dimensi Waktu, dimensi Barang, dimensi Satuan, dimensi Supplier, dan dimensi Signature.

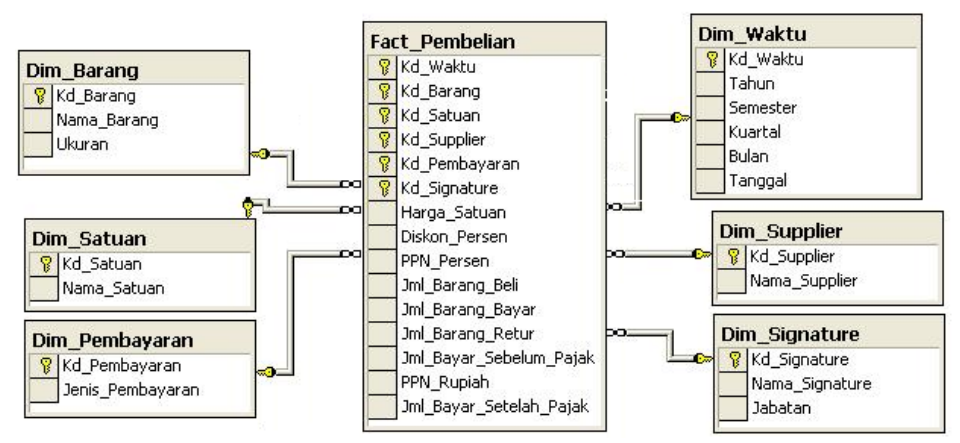

Gambar 3 Skema Bintang Fakta Pembelian

Skema Bintang Kontrol Stok menunjukkan kegiatan pengontrolan atau pengaturan Barang pada Gudang. Pada skema ini, informasi yang dapat diperoleh adalah mengenai jumlah barang awal, jumlah barang yang masuk ke gudang, jumlah barang yang keluar dari gudang dan jumlah barang yang tersisa di gudang. Data yang ada dapat dilihat berdasarkan dimensi Waktu, dimensi Barang, dimensi Satuan, dan dimensi Gudang.

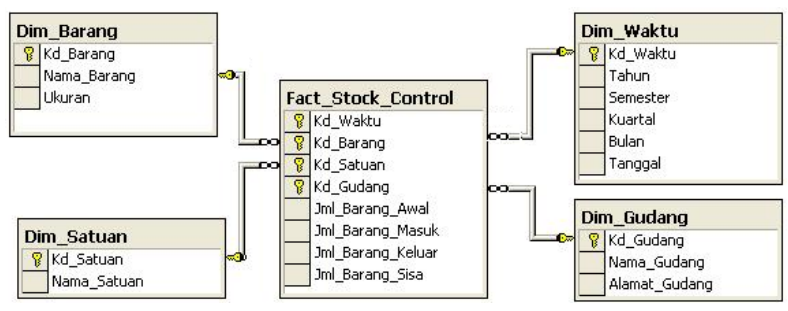

Gambar 4 Skema Bintang Fakta Kontrol Stok

\section{Struktur Menu Aplikasi}

Untuk menggambarkan keseluruhan menu yang terdapat di dalam aplikasi data warehouse pada PT Pelita Tatamas Jaya, dirancang hirarki struktur menu sebagai berikut:

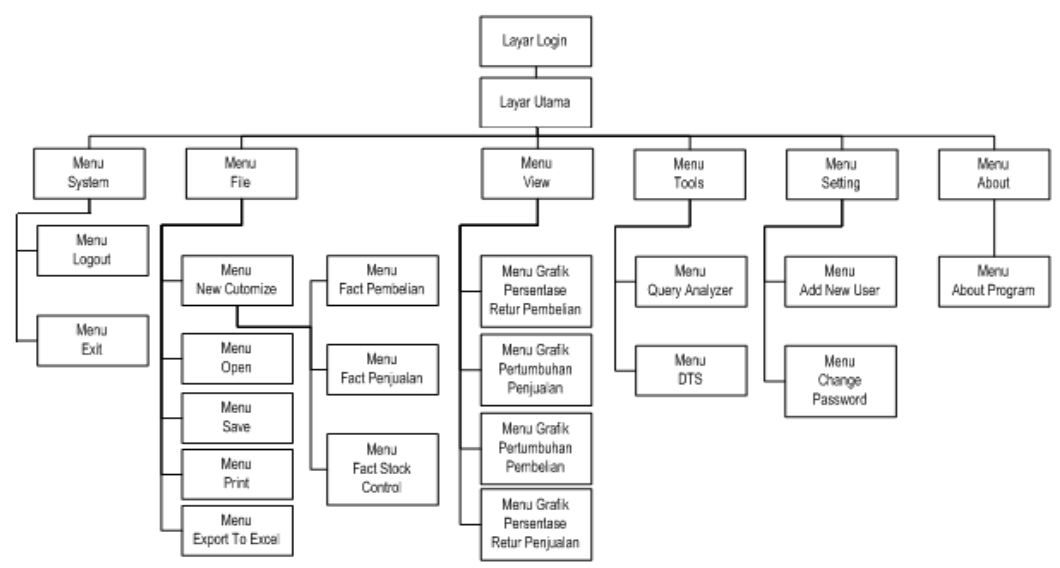

Gambar 5 Struktur Menu pada Layar Utama 


\section{Tampilan Hasil Aplikasi}

Berdasarkan atas rancangan tersbut, dihasilkan aplikasi data warehouse yang memiliki tampilan hasil antara lain:

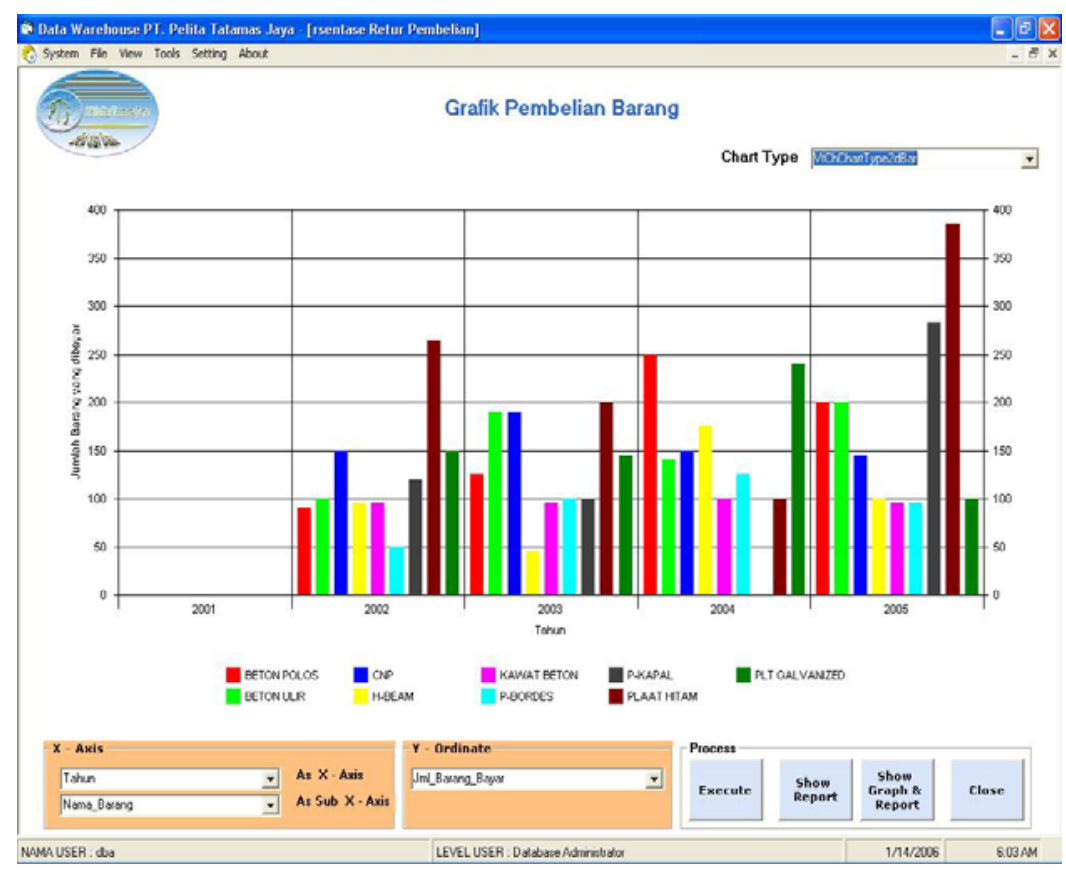

Gambar 6 Layar Analisis Data Pembelian Barang

Fitur ini berfungsi untuk melakukan proses analisis data dan informasi pembelian barang yang terjadi di perusahaan dengan berbagai dimensi.

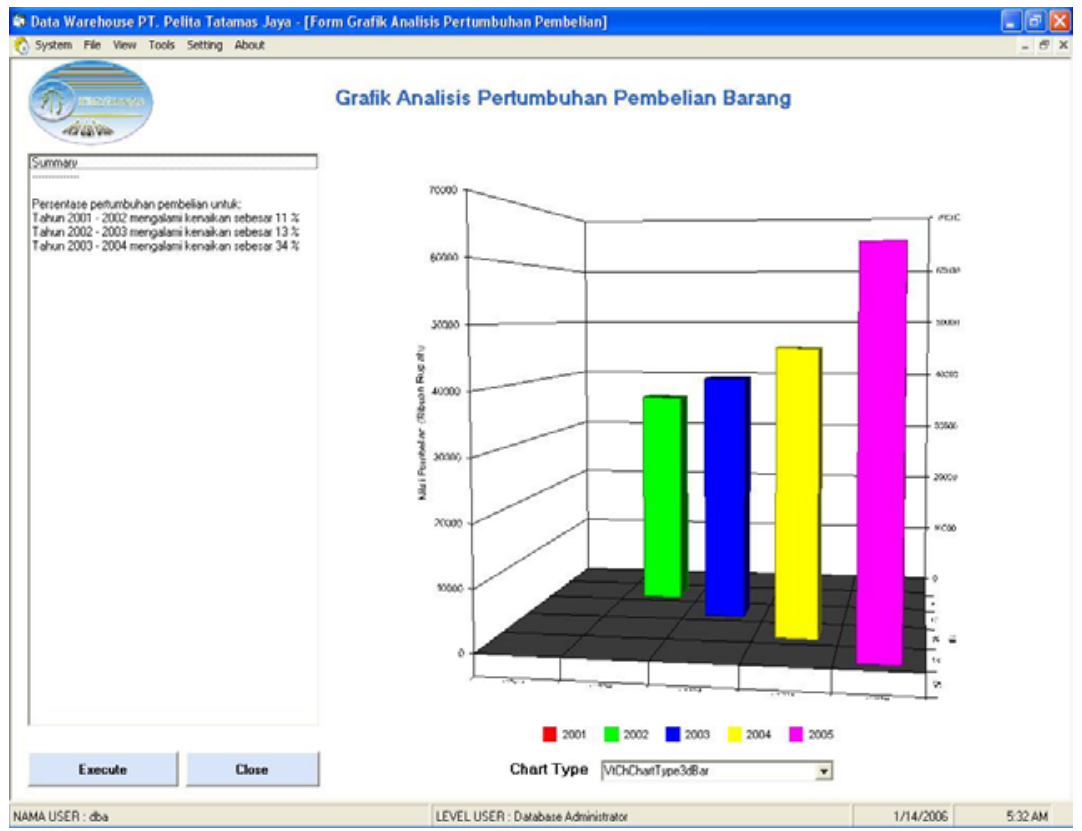

Gambar 7 Layar Analisis Persentase Pertumbuhan Pembelian Barang 
Fitur ini berfungsi untuk membantu penganalisaan pertumbuhan tingkat pembelian seluruh barang dari tahun-tahun sebelumnya sampai tahun terkini, sehingga dapat diketahui persentase tingkat pembelian barang secara keseluruhan setiap tahunnya.

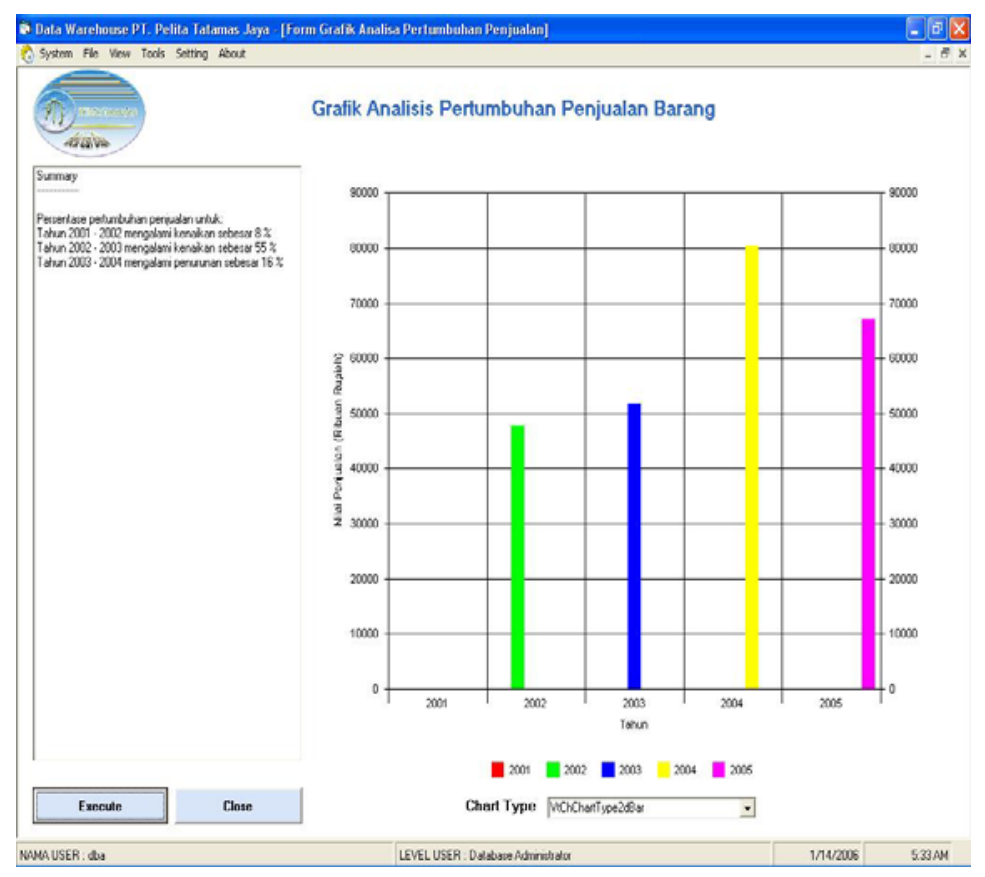

Gambar 8 Layar Analisis Pertumbuhan Penjualan

Fitur ini berfungsi untuk melakukan proses analisis data dan informasi penjualan barang yang terjadi di perusahaan dengan berbagai dimensi, sehinggga dapat diketahui persentase tingkat penjualan barang secara keseluruhan setiap tahunnya.

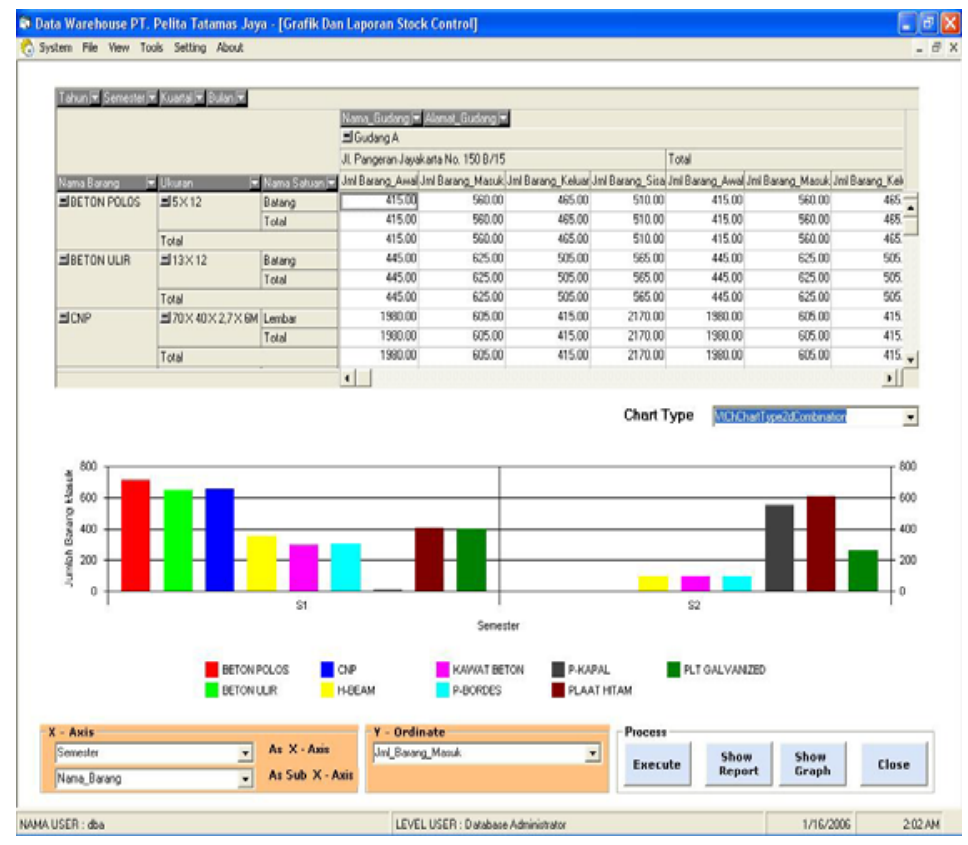

Gambar 9 Layar Analisis Stok Barang. 
Fitur ini berfungsi untuk membantu analisa stok barang, shingga dapat diketahui tingkat perubahan stok barang secara umum.

\section{Rencana Implementasi}

Untuk mengimplementasikan aplikasi data warehouse ini, perlu dukungan perangkat keras maupun piranti lunak terkait yang memadahi. Spesifikasi perangkat keras meliputi komponen server, minimal PC dengan processor Pentium IV Core 2 duo, memory 4 GB, Harddisk 240 GB,Penghubung jaringan (Hub/LAN). Komponen berikutnya adalah client, minimal PC dengan processor Pentium IV Core 2 duo, memory 2 GB, Harddisk 20 GB. Komponen ketiga Network Interface Card (NIC) yang diletakkan pada setiap server dan client agar dapar saling berhubungan. Komponen keempat adalah Switch/Hub yang digunakan untuk menghubungkan client ke server. Dari sisi piranti lunak, diperlukan DBMS Microsoft SQL Server 2000 SP2, dan Program Aplikasi Data Warehouse.

Tabel 12 Jadwal Rencana Implementasi

\begin{tabular}{|c|c|c|c|c|c|c|c|c|}
\hline \multirow{2}{*}{ Aktivitas } & \multicolumn{8}{|c|}{ Minggu } \\
\hline & 1 & 2 & 3 & 4 & 5 & 6 & 7 & 8 \\
\hline \multicolumn{9}{|l|}{ Instalasi $\mathrm{h} / \mathrm{w}$ dan s/w } \\
\hline \multicolumn{9}{|l|}{ Transformasi data } \\
\hline \multicolumn{9}{|l|}{ Uji coba aplikasi } \\
\hline \multicolumn{9}{|l|}{ Pelatihan pemakai sistem } \\
\hline \multicolumn{9}{|l|}{ Evaluasi hasil pelatihan } \\
\hline Evaluasi sistem & & & & & & & & \\
\hline
\end{tabular}

\section{Evaluasi}

Dari evaluasi yang dilakukan, aplikasi data warehouse memiliki fungsi-fungsi yang mampu menampilkan informasi terkait pembelian, penjualan, produksi, dalam format grafikal maupun tabel dengan kemampuan drill down dan drill up, dan dapat dikaji lintas dimensional. Transformasi data dari sumber data ke data warehouse dapat dilakukan dengan baik dan benar.

\section{SIMPULAN}

Setelah melakukan analisis dan perancangan Data Warehouse pada PT. Pelita Tatamas Jaya, penulis menarik simpulan Data Warehouse yang diusulkan dapat digunakan untuk mendukung kegiatan analisis sebagai dasar pengambilan keputusan oleh pihak eksekutif pada PT Pelita Tatamas Jaya. Informasi dari aplikasi sistem data warehouse pada PT. Pelita Tatamas Jaya merupakan pengetahuan bagi pihak eksekutif perusahaan yang dapat dikembangkan untuk menentukan strategi penjualan pada perusahaan disamping penentuan kebijakan pembelian dan pengawasan persediaan barang. 


\section{DAFTAR PUSTAKA}

Inmon, W. H. (2002). Building the Data Warehouse (3rd ed.). Canada: John Wiley \& Sons.

Poe, V., et al. (2001). Building the Data Warehouse a Decision Support (2nd ed.). United States of America: Prentice Hall.

Connolly, T., \& Begg, C. (2005). Database Systems: a Practical Approach in Design, Implementation, and Management (4th ed.). USA: Longman. 